\title{
DUSZPASTERZE PARAFIl DRUŻBIN (OD XVI WIEKU)
}

W studiach nad dziejami każdej parafii wiele uwagi poświęca się ludziom z nią związanym, a zwłaszcza jej duszpasterzom, których działalność ma wielki wpływ na życie duszpasterskie w parafii, budownictwo sakralne, a także na działalność zewnętrzną całej wspólnoty parafialnej, taką jak działalność społeczna, kulturalna, narodowa, charytatywna itp. Badania nad życiorysami duchownych pokazują również wpływ ich pochodzenia społecznego na działalność w parafii oraz ówczesne podejście do duszpasterstwa.

Biogramy duchownych od XIX wieku są dość łatwe do opracowania, gdyż nawet $\mathrm{w}$ przypadku braku teczki personalnej ważniejsze wydarzenia z życia każdego księdza można odnaleźć w schematyzmach, nierzadko drukowano też biogramy kapłanów w ówczesnej prasie. Natomiast $\mathrm{w}$ badaniach wcześniejszych trzeba opierać się głównie na wzmiankach zamieszczanych $\mathrm{w}$ aktach wizytacji kanonicznych, które niestety nie były zbyt częste, a i wizytator nie zawsze podawał dokładne dane, dlatego że zainteresowany często nie był obecny w czasie wizytacji.

" Ks. dr hab. Wojciech Frątczak - kierownik Zakładu Historii Kościoła (nowożytnej) na Wydziale Teologicznym UMK w Toruniu. 
Akta personalne w diecezji włocławskiej zaczęto prowadzić dość późno, chyba w końcu XIX wieku. Do ich zaprowadzenia przyczyniło się żądanie władz zaborczych, które pilnie śledziły poczynania duchownych i chciały o nich jak najwięcej wiedzieć.

Niniejsze opracowanie zawiera biogramy duchownych pracujących w parafii Drużbin od XVI wieku. Nie są one kompletne, parafia ta często zmieniała bowiem przynależność dekanalną, co sprawiało, że nierzadko pomijano ją w wizytacjach, ponieważ przechodziła do dekanatu, w którym wizytacja już się odbyła, a w poprzednim jeszcze jej nie było.

Proboszczowie często nie rezydowali w parafiach z różnych przyczyn. Uposażenie parafii było zapłatą lub sposobem na utrzymywanie różnych urzędników, a nawet profesorów seminarium duchownego. Duszpasterstwo sprawowali za nich wikariusze bądź zakonnicy. Ich nazwiska i dane personalne, o ile są znane, są przedstawione razem z danymi proboszcza, z którym współpracowali lub za którego prowadzili duszpasterstwo.

\section{Ks. Jan Rudnicki}

Pierwszy znany z nazwiska proboszcz parafii wymieniony przez Liber beneficiorum Jana Łaskiego (spisany w całej archidiecezji w latach 1511-1523). ${ }^{1}$ Nie rezydował w parafii, ale utrzymywał na własny koszt nieznanego z nazwiska wikariusza.

\section{Ks. Stanisław Hotnieński}

Wymieniony w aktach wizytacji kanonicznej parafii Drużbin w $1683 r^{2}$

\section{Ks. Jan Iwański}

Wymieniony w aktach wizytacji kanonicznej w 1711 r. Był kanonikiem uniejowskim. Parafię Drużbin otrzymał z polecenia właściciela Drużbina, Stanisława Trzebnickiego. Instalacji na proboszcza dokonał w parafii ks. Jan Gałczyński, dziekan i oficjał uniejowski. Jako kanonik zapewne $\mathrm{w}$ parafii nie rezydował.

${ }^{1}$ J. Łaski, Liber beneficiorum, t. 1, Gniezno 1880, s. 396.

2 Archiwum Diecezjalne we Włocławku (ADWł), Akta arcybiskupów gnieźnieńskich (AAG). Wizytacje (Wiz.) 8, s. 71. 


\section{Ks. Chryzostom Czyżewski, do 1747 roku}

Występuje w czasie wizytacji w 1728 r., był proboszczem do 1747 r. Dziekan dekanatu uniejowskiego. Ponieważ sam prowadził księgi metrykalne, a jego wikariuszem był diakon, należy wnioskować, że rezydował w parafii ${ }^{3}$. Wiadomo, że przekazał dworowi w Drużbinie jaką́ rolę parafialną we wsi Rzechta. Było to prawdopodobnie zadośćuczynienie lub zamiana za inne role przejęte przez jego poprzednika.

Wikariuszem w Drużbinie w tym czasie był diakon Tomasz Rossowski ${ }^{4}$.

Ks. Antoni Wilkanowski, 1747-1779

Pochodził ze znaczącego rodu szlacheckiego w województwie łęczyckim. Urodził się około 1706 r. Wyświęcony na kapłana przez biskupa sufragana gnieźnieńskiego Józefa Trzcińskiego w 1733 r. Mianowany kanonikiem łęczyckim w 1736, kustoszem archikolegiaty łęczyckiej w 1739, dziekanem uniejowskim w 1741 r. Proboszczem w Drużbinie został w 1747 lub 1748 r. ${ }^{5}$ Nie wiadomo dokładnie, kiedy został kanonikiem w kapitule katedralnej w Poznaniu, ale było to przed 1779 r. Na kumulację beneficjów miał dyspensę z Rzymu. W parafii nie rezydował. ${ }^{6}$ Wizytator widocznie nie był do niego nastawiony życzliwie, nie szczędził mu bowiem uszczypliwych uwag.

Spośród wikariuszy drużbińskich znani są z tego czasu: ks. Marian Głoskowski, wymieniony w 1759 r.; bernardyn z Warty, od 1764 r., wymieniony w 1765 r.

\section{Ks. Kazimierz Petrykowski, 1779-1780}

Urodził się w rodzinie mieszczańskiej w parafii Pabianice. W 1757 r. ukończył szkołę w Piotrkowie Trybunalskim. Święcenia niższe otrzymał w 1778 r., w rok później święcenia wyższe, a święcenia kapłańskie 18 VII 1779 r. Wszystkie święcenia przyjął z rąk bp. Kornela Przedwojewskiego w kolegiacie łowickiej ${ }^{7}$. Prowizję na Drużbin dostał 9 X 1778 r., czyli rok przed święceniami kapłańskimi ${ }^{8}$. Do Drużbina przybył po

${ }^{3}$ ADWł, AAG. Wiz. 13, s. 37.

${ }^{4}$ Tamże.

${ }^{5}$ ADWl, AAG. Wiz. 59, s. 93.

${ }^{6}$ ADWl, AAG. Wiz. 72, s. 1037.

7 Antoni Przedwojewski, biskup tytularny Bolino (1728-1793), były prowincjał kapucynów, sufragan gnieźnieński.

${ }^{8}$ ADWł, AAG. Wiz. 72, s. 1037. 
święceniach jako neoprezbiter. Głosił kazania świąteczne i niedzielne, katechizował, używając aprobowanych podręczników. Wizytator w 1779 r. wydał o nim jak najlepszą opinię.

\section{Ks. Mikołaj Obrokczyński, 1781-1819}

Urodził się 28 października 1746 r. Wyświęcony na kapłana 4 VI 1775 r. Mianowany proboszczem w Drużbinie od 8 lutego 1781 r., z prezenty Jana i Kunegundy z Mączyńskich Jabłkowskich, cześnikostwa szadkowskiego. Prezentę tę otrzymał 24 IV 1781 r. w Skierniewicach. Rekolekcje odprawiał w Lutomiersku, zgodnie z nakazem konsystorza. Prymas Michał Jerzy Poniatowski dokumentem wystawionym w Warszawie dnia 2 VIII 1785 r. mianował go dziekanem uniejowskim, a z dniem 3 I 1786 r. egzaminatorem synodalnym w swoim dekanacie ${ }^{9}$. Nie wiadomo, w jakim czasie otrzymał nominację na kanonika honorowego uniejowskiego. Zmarł jako proboszcz w parafii Drużbin w 1819 r. Zapisał do biblioteki parafialnej książki za sumę $130 \mathrm{zł}^{10}$.

Wikariusz ks. Michał Kułakowski występuje w czasie wizytacji w parafii 4 IX 1820 r., a w 1821 r. - jako administrator po śmierci proboszcza.

\section{Ks. Jan Szymański, 1822-1857}

Urodził się 12 grudnia 1793 r. Święcenia kapłańskie otrzymał w 1817 r. Wikariuszem parafii Drużbin mianowany w 1822 r., następnie od 1823 r. komendarzem w tej parafii, a wreszcie w 1850 r. został jej proboszczem. Pracował w niej aż do śmierci w dniu 12 lutego 1857 r. Od 1845 r. był wicedziekanem, a od 1851 r. dziekanem dekanatu lutomierskiego. W 1847 r. został mianowany kanonikiem honorowym w kolegiacie kaliskiej. Zmarł w 40 roku kapłaństwa, przeżywszy 64 lata ${ }^{11}$.

\section{Ks. Hieronim Aranowski, 1857-1878}

Urodził się 2 lutego 1821 r. Wstąpił do zakonu Braci Mniejszych Prowincji Matki Bożej Anielskiej (reformaci) i tam przyjął święcenia kapłańskie w 1844 r. Jego dzieje w zakonie w latach 1844-1853 nie są znane. W 1853 r.(?) notowany jest jako wikariusz w parafii Lubraniec, praw-

9 ADWł, AAG. Wiz. 88, s. 58.

10 ADWŁ, AAG. Wiz., s. 75.

11 Elenchus pro anno 1858, s. 42. W 1822 r. błędnie pisano w schematyzmach jego imię jako Józef. 
dopodobnie tylko w tym roku, bo w następnym nie występuje nigdzie, a następnie w Szadku (1854?-1857). Prawdopodobnie w tych latach został sekularyzowany, przy jego nazwisku brak bowiem określenia przynależności zakonnej. W 1857 r. został komendarzem w Drużbinie po śmierci J. Szymańskiego. Zmarł 10 stycznia 1878 r., w 59 roku życia, a 34 roku kapłaństwa, i został pochowany na cmentarzu parafialnym w Drużbinie ${ }^{12}$.

\section{Ks. Roch Rendschmidt, 1854-1896}

Był synem Franciszka i Katarzyny z Mauerów, urodzonym 27 lipca 1830 r. w Wieluniu. Po ukończeniu miejscowej szkoły powiatowej w 1846 r., w wieku 16 lat wstąpił do zakonu Bernardynów w Świętej Annie pod Przyrowem. Przyjął imię zakonne Pantaleon. Studia zakonne ukończył w Warszawie. Święcenia kapłańskie przyjął 6 I 1854 r. we Włocławku od ówczesnego miejscowego sufragana, bp. Tadeusza Łubieńskiego. W zakonie pełnił obowiązki kaznodziei w klasztorach: Góra Kalwaria, Święta Anna, Łęczyca. Po kasacie zakonów w 1864 r. przewieziony z Łęczycy do Widawy. W diecezji włocławskiej pełnił najpierw obowiązki wikariusza parafii Strońsko (9 XI 1866-30 VII 1868), a następnie proboszcza parafii: Kamionacz (30 VII 1868-20 III 1878), Drużbin (20 III 1878-29 IV 1896), Skęczniew (29 IV 1896-11 V 1907) i Niedośpielin (od 11 V 1907). Sekularyzował się w kwietniu 1874 r., ale prawdopodobnie jest to pomyłka, ponieważ w innym miejscu napisano, że dokument sekularyzacyjny Stolicy Apostolskiej otrzymał w Drużbinie. Potwierdza to także ówczesna prasa, która w poprzedniej parafii nazywa go „bernardynem”, a w Drużbinie już nie. Zmarł w Niedośpielinie 9 stycznia 1909 r. ${ }^{13}$ Ówczesna prasa chwaliła go za czynne angażowanie się w sprawy parafii, a zwłaszcza za remonty zaniedbanych świątyń ${ }^{14}$.

\section{Ks. Ignacy Chartliński, 1896-1919}

Urodził się 27 lipca 1866 r. w Sieradzu. Po ukończeniu studiów filozoficzno-teologicznych w seminarium duchownym we Włocławku (1884-1889) został wyświęcony na kapłana 3 II 1889 r. Jako wikariusz pracował w parafii Łask (1889-1891) i Raciążek (XII 1891-1893). Następnie

12 „Przegląd Katolicki” 1878, s. 73; A. Poniński, Biogramy kapłanów diecezji włocławskiej, baza komputerowa w posiadaniu jej autora.

${ }_{13}$ „Kronika Diecezji Kujawsko-Kaliskiej” 3 (1909), s. 18; R. Prejs, Stownik biograficzny zakonników franciszkańskich Królestwa Polskiego po kasacie 1864 r., Poznań 2004, s. 157.

14 „Przegląd Katolicki” 1869, s. 604. 
został administratorem parafii Ostrowite Słupeckie (1893-1894); Mieleszyn (15 III 1894-1896); Drużbin (1896-1919) i Działoszyn, gdzie w 1925 r. zastał go podział diecezji. Wówczas znalazł się w diecezji częstochowskiej. W nowo utworzonej diecezji był w 1926 r. członkiem komisji a vigilantia i radcą Kurii.

Po wybuchu II wojny światowej został zamordowany przez Niemców na swojej plebanii w Działoszynie 1 lub 2 września 1939 r. ${ }^{15}$

\section{Ks. Ignacy Rechciński, 1919-1922}

Urodził się 23 lipca 1876 r. W latach 1897-1903 odbył studia w seminarium duchownym we Włocławku i przyjął święcenia kapłańskie. Po święceniach był z niewiadomych przyczyn w latach 1903-1905 bez zatrudnienia, a następnie pracował jako wikariusz w Słupcy (1905-1908) i Turku (1908-1909). Później był rektorem kościoła poklasztornego w Choczu (VI 1909-1916). Pierwszą jego samodzielną placówką duszpasterską była parafia Niewiesz (1916-1919), następnymi: Drużbin (ok. XI 1919-1922) i Czarnożyły (ok. X 1922-1931). Prawdopodobnie w 1931 r. wstąpił do klasztoru Paulinów w Leśnej i przyjął imię Wiktor, a następnie pracował $\mathrm{w}$ innych klasztorach paulińskich ${ }^{16}$.

\section{Ks. Julian Godlewski, 1922-1926}

Urodził się 13 lipca 1874 r. Po odbyciu studiów filozoficzno-teologicznych w seminarium duchownym we Włocławku (1894-1898) otrzymał święcenia kapłańskie 19 czerwca 1898 r. Po święceniach pracował jako wikariusz w parafiach Russocice (1901-1904) i Błaszki (1904-1908) W 1908 r. został administratorem parafii Sędzin, a następnie pracował na tym samym stanowisku w kolejnych parafiach: Koneck (1910-1913), Trąbczyn (1913-1918), Charłupia Wielka (1918-1922). Po wybuchu wojny Polski z Rosją sowiecką zgłosił się na kapelana wojskowego. Przez jakiś czas był proboszczem parafii wojskowej w Rembertowie. Po zwolnieniu z wojska 15 VII 1921 r. wrócił do Charłupi Wielkiej, skąd 10 X 1922 r. przeszedł do Drużbina. Kto go zastępował w czasie dwuletniej nieobecności i jaki był jego status po powrocie z wojska, nie wiadomo. Z Drużbina przeszedł na probostwo w Białotarsku (16 III 1932-19 XII 1932). Kolej-

15 „Przegląd Katolicki” 1895, s. 216; Martyrologium polskiego duchowieństwa rzymskokatolickiego pod okupacja hitlerowskg 1939-1945, z. 2, Warszawa 1977, s. 139. Tamże data urodzenia: 26 VII.

16 A. Poniński, dz. cyt. 
no był proboszczem w Chełmnie (19 XII 1932-11 IV 1934), Lubstowie (11 IV 1934-20 IV 1937) i Ostrowążu, gdzie przybył 20 IV 1937 r. i pracował do aresztowania go przez Niemców w dniu 6 X 1941 r. Przewieziony do obozu koncentracyjnego w Dachau 30 X 1841 r., został umieszczony na bloku 28 (nosił numer 28 208), skąd jako niezdolny do pracy został 6 marca 1942 r. wywieziony przez oprawców niemieckich na śmierć przez zagazowanie ${ }^{17}$.

\section{Ks. Paweł Bobotek, 1926-1930}

Urodził się 22 kwietnia 1872 r. Po ukończeniu seminarium duchownego we Włocławku otrzymał święcenia kapłańskie 29 VI 1897 r. Po święceniach pracował jako wikariusz w Zadzimu z rezydencją w Osjakowie. Było to spowodowane ograniczeniami carskimi, które po zaborze ziem kościelnych dawały duchownym pensje, ale według z góry wyznaczonych stanowisk. Jeśli jakiś starszy kapłan potrzebował pomocy, to nie mógł mieć wikariusza, bo według zarządzenia rosyjskiego wikariusz mu nie przysługiwał. Stąd władza kościelna mianowała wikariusza zgodnie z poleceniami carskimi, a rezydował tam, gdzie był bardziej potrzebny. Kolejne wikariaty to: Praszka (1901-1903) i Strońsko (1903-1907).

Pierwszą jego samodzielną placówką duszpasterską była parafia Dobryszyce (1907-1913), a następnymi: Skęczniew (1913-1922), Kosmów (1922-1932), Borysławice (1932-1936) i Broniszewo na Kujawach (od 1936 r.). Aresztowany przez Niemców 24 X 1939 r. wraz z księżmi dekanatu radziejowskiego, został osadzony w Piotrkowie Kujawskim, skąd Niemcy zabrali go i rozstrzelali w pobliżu miasta 24 X 1939 r. Po wojnie ciała zostały ekshumowane i pochowane na miejscowym cmentarzu parafialnym w Piotrkowie Kujawskim ${ }^{18}$.

\section{Ks. Stefan Trzask, 1930-1932}

Syn Wincentego i Marii z Kopjasów, urodził się 14 IV 1894 r. w Pabianicach. W 1912 r. ukończył miejscową szkołę handlową, następnie podjął pracę jako urzędnik, a także nauczyciel w szkole wiejskiej, potem w progimnazjum w Pabianicach. Do seminarium duchownego we Włocławku został przyjęty we wrześniu 1915 r. i po jego ukończeniu otrzymał święcenia kapłańskie 13 VI 1920 r.

${ }^{17}$ S. Librowski, Ofiary zbrodni niemieckiej spośród duchowieństwa diecezji włoctawskiej 1939-1945, Włocławek 1947, s. 37.

${ }_{18}$ Tamże, s. 10-11. 
Po święceniach został wikariuszem w Brzeźniu, skąd po półrocznym pobycie przeszedł do Milejowa, gdzie chorował na płuca. Kolejnymi jego placówkami wikariuszowskimi były parafie: Russocice (21 VIII-21 XII 1921), Izbica (22 XII 1921-11 IX 1924), Radziejów, gdzie pełnił funkcję prefekta progimnazjum i rektora kościoła pofranciszkańskiego (12 IX 1924-29 VII 1926).

Pierwszą jego samodzielną placówką duszpasterską była parafia Myślibórz (30 VII 1926-24 X 1927), a następnymi: Dobrosołowo (25 X 1927-3 X 1930), Drużbin (4 X 1930-31 VII 1932), Zbrachlin (1 VIII 1932-2 XII 1935), Giżyce (3 XII 1935-6 X 1941).

Aresztowany przez Niemców 6 X 1941 r., został wywieziony do obozu przejściowego w Konstantynowie, a następnie 30 X 1941 r. do Dachau. Mieszkał w bloku 28 i nosił numer 28 279. Zmarł w obozie 13 listopada $1942 \mathrm{r}$. Jego ciało spalono w miejscowym krematorium ${ }^{19}$.

\section{Ks. Aleksander Kokczyński, 1932-1948}

Syn Antoniego i Heleny z Dzierżawskich, urodził się 6 I 1877 r. w Grabkowie koło Malanowa. Po ukończeniu pięciu klas gimnazjum filologicznego w Kaliszu wstąpił do seminarium duchownego we Włocławku. Święcenia przyjął 29 VI 1901 r. Po święceniach pracował jako wikariusz w Iwanowicach (1901-1902), a następnie w parafii św. Mikołaja w Kaliszu (dziś katedra kaliska) do 1909 r.

Jego pierwszą samodzielną placówką duszpasterską było probostwo w Rychnowie (1909-1931), a następnie przejściowo parafia Piątek Wielki, gdzie był tymczasowym administratorem. Ostatnią placówką, którą otrzymał, był Drużbin (od 13 VIII 1932).

W Drużbinie pozostał aż do lat powojennych. W czasie II wojny światowej, choć był ciężko chory i został wyrzucony z plebani, pozwolono mu mieszkać niedaleko kościoła. W miarę sił sprawował duszpasterstwo, ale $\mathrm{w}$ wielu wypadkach przychodził mu z pomocą sąsiad $\mathrm{z}$ Niemysłowa, ks. Stanisław Ławiński. Po wojnie, niedołężny ze starości, nie chciał przenieść się do domu emerytów, a wikariusza z powodu powojennego braku księży nie mógł dostać. Postanowił zamieszkać u swego wychowanka Bolesława Pietrasa na terenie parafii Piątek Wielki, ale po kilku miesiącach przeniósł się do domu księży emerytów w Ciechocinku, gdzie zmarł 7 sierpnia 1951 r. i tam został pochowany.

19 Tamże, s. 155-156. 


\section{Ks. Wincenty Roman Wiliński, 1948-1949}

Urodził się 8 lipca 1915 r. w Witowie na Kujawach. Wykształcenie średnie zdobył we Włocławku, uczęszczając do Gimnazjum im. ks. Jana Długosza. W 1934 r. rozpoczął studia w Wyższym Seminarium Duchownym we Włocławku. Wybuch II wojny światowej zastał go na ostatnim roku. Miał jednak szczęście, że nie został zatrzymany w czasie aresztowania kleryków i profesorów. Naukę dokończył w Lądzie, gdzie byli internowani profesorowie seminarium i alumni. Po skończeniu seminarium otrzymał dimisorium do święceń i na tej podstawie biskup łódzki Włodzimierz Jasiński udzielił mu święceń kapłańskich 29 września 1940 r.

Po przyjęciu święceń wrócił do rodzinnego Witowa i pomagał miejscowemu proboszczowi ks. Borysewiczowi w pracy duszpasterskiej. W 1941 r. został wysiedlony do tzw. Generalnej Guberni, do Międzyrzecza Podlaskiego. Najpierw pełnił tam funkcję kapelana zakładu dla sierot, a od 15 marca 1941 r. do 1 lutego 1944 r. był wikariuszem parafii Opieki św. Józefa i kapelanem szpitala.

Po wojnie wrócił do rodzinnej diecezji, podejmując pracę $\mathrm{w}$ wielu parafiach. Od lutego do sierpnia 1945 r. był administratorem parafii Rychwał i jednocześnie obsługiwał parafie Grochowy i Królików, następnie był wikariuszem parafii Wniebowzięcia NMP w Kaliszu. Od 28 XI 1948 r. do 29 IX 1952 r. był administratorem parafii Zadzim i dodatkowo przez cztery miesiące na przełomie roku 1948 i 1949 administrował parafią Drużbin.

Dnia 28 września 1952 r. został proboszczem parafii Miłosierdzia Bożego w Kaliszu, gdzie pracował aż do swej śmierci w dniu 21 lipca 1982 r. Był budowniczym tamtejszej monumentalnej świątyni, której nie zdołał wykończyć. Został pochowany w Kaliszu na tamtejszym cmentarzu komunalnym. Był szambelanem papieskim (od 1963 r.), kanonikiem kapituły kolegiackiej w Kaliszu (od 1975 r.), a od 1971 r. aż do śmieci dziekanem dekanatu kaliskiego II $^{20}$.

\section{Ks. Józef Minet, 1949-1984}

Syn Bronisława i Apolonii z Pajewskich, urodził się 2 maja 1912 r. w Dąbrówce (parafia Borkowo w diecezji płockiej). Maturę uzyskał $\mathrm{w}$ gimnazjum humanistycznym im. Prezydenta Ignacego Mościckiego w Sierpcu, a następnie w latach 1935-1936 odbył służbę wojskową, jako kapral podchorąży, w 13 p.p. w Pułtusku i Modlinie.

${ }^{20}$ T. Lewandowski, Ks. prałat Wincenty Wiliński, „Kronika Diecezji Włocławskiej” (KDWł) 66 (1983), s. 46-48. 
Do Wyższego Seminarium Duchownego we Włocławku wstąpił w 1936 r. Niestety po trzech latach naukę przerwał wybuch II wojny światowej. Okres okupacji spędził w domu rodzinnym, pracując $\mathrm{w}$ gospodarstwie u rodziców, a następnie w majątkach niemieckich.

Po wyparciu Niemców wrócił natychmiast do Włocławka, gdzie przyjął go ks. prof. Stefan Wyszyński, pełniący w tym czasie obowiązki rektora. Seminarium ukończył 30 VI 1946 r., przyjmując święcenia kapłańskie.

W latach 1946-1949 pracował jako wikariusz w parafiach Brzeźno, Lipno i Błaszki. Następnie został administratorem parafii Drużbin. $Z$ tą parafią pozostał związany przez swoją pracę aż do śmierci. Z dużą gorliwością i oddaniem służył swoją posługą duszpasterską nie tylko swojej parafii, ale także sąsiednim. Wielokrotnie pełnił dodatkowo funkcję administratora parafii Wierzchy, Zygry, Niemysłów i Zadzim. W uznaniu jego zasług biskup włocławski Jan Zaręba odznaczył go przywilejem używania rokiety i mantoletu. Zmarł 3 maja 1984 r. po ciężkiej chorobie. Pochowany na cmentarzu parafialnym w Drużbinie ${ }^{21}$.

\section{Ks. Jan Talaska, 1984-1985}

Syn Andrzeja i Wiktorii Kubarek, urodził się 18 czerwca 1931 r. w Pyzdrach. Wcześnie zmarła mu matka, a ojca zakatowali Niemcy. Osierocone dzieci wychowali sąsiedzi. Dzięki uporowi i determinacji udało mu się ukończyć szkołę średnią, najpierw trzy lata uczył się u salezjanów w Lądzie nad Wartą, następnie rok w gimnazjum we Wrześni, gdzie otrzymał małą maturę. Świadectwo maturalne uzyskał w Niższym Seminarium Duchownym we Włocławku w 1951 r. W latach 1951-1957 ukończył Wyższe Seminarium Duchowne we Włocławku i 14 VII 1957 r. przyjął święcenia kapłańskie z rąk bp. Antoniego Pawłowskiego.

Po święceniach pracował jako wikariusz w następujących parafiach: Chełmce (1957), Kikół (1957-1958), Goszczanów (1958-1959), Russocice (1959), Szadek (1959-1960), następnie jako prefekt w szkołach włocławskich i wikariusz parafii św. Stanisława we Włocławku (1960-1961), w Błaszkach (1961-1962) i w Radziejowie (1962). W latach 1962-1963 pracował $\mathrm{w}$ diecezji gorzowskiej jako wikariusz parafii Jesionów i Bobrownice. Wrócił do diecezji włocławskiej i pracował w Białotarsku (1964-1965) i Sompolnie (1965-1967).

${ }^{21}$ W. Frątczak, Ks. Józef Minet, KDWł 67 (1984), s. 239. 
Pierwszą jego samodzielną placówką duszpasterską była parafia Dębno Królewskie (1967-1971), gdzie wybudował plebanię i dzwonnicę. Następnie był proboszczem w Miłkowicach (1971-1975), gdzie przyczynił się do kupna nowych dzwonów. W 1975 r. został przeniesiony do Tłokini, a po sześciu miesiącach do parafii Grochowy (1975-1979). Po rocznym urlopie zdrowotnym został proboszczem w Ostrowitem Lipnowskim (1980-1983), a następnie kolejno w: Działyniu (1983-1984), Drużbinie (1984-1985) i Charłupi Wielkiej (1985-1987). Przeniesiony na emeryturę, zamieszkał w domu księży emerytów w Koninie. Choroba psychiczna, która rozwijała się coraz bardziej, uniemożliwiła mu dalszą pracę i przyczyniła się do jego tragicznej śmierci 17 czerwca $1998 \mathrm{r}$. Został pochowany w rodzinnym grobie w Pyzdrach ${ }^{22}$.

\section{Ks. Stanisław Kazimierz Włodarkiewicz, 1985-1993}

Urodził się 13 XI 1943 r. w małorolnej rodzinie wiejskiej jako jeden z siedmiorga dzieci Piotra i Katarzyny z Rogowskich. Został ochrzczony dopiero po wojnie, 22 kwietnia 1946 r., w kościele parafialnym w Rzgowie. Tam też ukończył szkołę podstawową w latach 1950-1958.

W latach 1958-1962 ukończył Państwowe Liceum Ogólnokształcące w Koninie i uzyskał świadectwo maturalne 30 V $1962 \mathrm{r}$. W tymże roku rozpoczął naukę w Wyższym Seminarium Duchownym we Włocławku. Po sześciu latach nauki ukończył seminarium i napisał pracę dyplomową z prawa kanonicznego. Święcenia kapłańskie przyjął 23 VI 1968 r. w kolegiacie Wniebowzięcia Najświętszej Maryi Panny w Kaliszu, z rąk biskupa włocławskiego Antoniego Pawłowskiego. W ramach dokształcania ukończył w latach 1975-1978 Studium Teologiczno-Pastoralne we Włocławku i na podstawie pracy „Polskie prawodawstwo wyznaniowe w zakresie życia duszpasterskiego i jego aplikacja $\mathrm{w}$ diecezji włocławskiej w latach 1918-1939" został dopuszczony do egzaminu magisterskiego, który zdał 22 I 1980 r. na KUL-u. Obowiązujący wówczas egzamin proboszczowski zdał 30 IV $1981 \mathrm{r}$.

Po święceniach pracował jako wikariusz we Wrzącej Wielkiej (24 VIII 1968-15 VI 1970), Trąbczynie (15 VI 1970-1 VII 1972), parafii Wniebowzięcia NMP w Zduńskiej Woli (1 VII 1972-1 II 1975). W tym czasie poważnie chorował i wiele miesięcy był na leczeniu, po którym został skierowany na urlop zdrowotny. Po urlopie zdrowotnym był wikariuszem w: Kramsku (16 VI 1975-20 VIII 1976), Ślesine (20 VIII 1976-29 IV

${ }^{22}$ Tenże, Ks. Jan Talaska, KDWł 81 (1998), s. 323-324. 
1978), Szadku (29 IV-10 VIII 1978), Choczu (10 VIII 1978-1 VII 1982) i w parafii św. Stanisława we Włocławku (1 VII 1982-30 VI 1985).

Pierwszą jego samodzielną placówką duszpasterską była parafia Drużbin (1 VII 1985-30 VI 1993), a następną Lisiec Wielki - od 1 VII 1993 r. do śmierci w dniu 2 IX 2008 r. Pochowano go w rodzinnej parafii w Rzgowie. W obydwu tych parafiach wykazał się ogromnym zaangażowaniem duszpasterskim i niezwykłą troską o powierzone sobie budynki sakralne. W uznaniu zasług został obdarzony przywilejem używania rokiety i mantoletu w 1996 r., a następnie został kanonikiem honorowym kapituły kolegiackiej w Uniejowie i w 2008 r. kapelanem papieskim ${ }^{23}$.

\section{Ks. Józef Kuś, 1993-1994}

Syn Józefa i Heleny Garczarek, urodził się 9 III 1945 r. w Żelazkowie (parafia Goliszew, dziś diecezja kaliska). Szkołę podstawową i liceum ogólnokształcące ukończył w Rudzie Śląskiej, gdzie przenieśli się jego rodzice $\mathrm{w}$ poszukiwaniu pracy. Ojciec pracował jako górnik $\mathrm{w}$ kopalni. Po otrzymaniu świadectwa dojrzałości w 1963 r. wstąpił do Seminarium Śląskiego w Krakowie, gdzie ukończył piąty rok. Po tym roku przeniósł się do Wyższego Seminarium Duchownego we Włocławku, motywując swój krok powrotem do stron rodzinnych. Po roku otrzymał święcenia kapłańskie 16 VIII 1969 r., z rąk administratora diecezji włocławskiej bp. Jana Zaręby.

Przebieg jego pracy kapłańskiej był następujący. Wikariusz w Szpetalu Górnym (1 IX 1969-28 II 1970), Zgłowiączce (10 IV 1970-31 VIII 1970), Wieleninie (31 VIII 1970-18 II 1971). Później skierowany do pomocy duszpasterskiej w Kole (18 II 1971-30 VI 1970). Kolejne wikariaty to: Giżyce (30 VI 1971-30 VI 1973), Klonowa (30 VI 1973-15 VII 1975), Chełmica Duża (15 VII 1975-15 VII 1976), Grzegorzew (15 VII 1976-15 VI 1978), Zagórów (15 VI 1978-16 VI 1979), Rajsko (16 VI 1979-23 IV 1980).

Po urlopie zdrowotnym został kapelanem sióstr w Rożdżałach, w parafii Rossoszyca (16 VI 1981). W tym czasie uczęszczał do Studium Teologiczno-Pastoralnego we Włocławku, które uwieńczył uzyskaniem stopnia magistrackiego z teologii w dniu 13 V 1983 r. Następnie skierowano go do pomocy duszpasterskiej w parafii św. Mikołaja w Kaliszu (30 VI 1984), a od 4 X 1985 r. był wikariuszem tej parafii (do 27 XI 1985 r.).

Jego pierwszą samodzielną placówką była administracja parafią Rychnów (27 XI 1985-16 VIII 1986), skąd po niecałym roku skierowano

${ }^{23}$ K. Rulka, Zmart ks. prat. Stanistaw Włodarkiewicz, "Miesięcznik Diecezji Włocławskiej - Kronika" (MDWł) 91 (2008), s. 918-932. 
go ponownie na leczenie. Po leczeniu mianowano go administratorem, a następnie proboszczem parafii Modzerowo (28 X 1988-30 VI 1999), skąd kolejny raz skierowano go na leczenie. Następnymi parafiami były probostwa w Drużbinie (30 VI 1993-30 VI 1994) i Koszutach (30 VI 1994-30 VI 1995). Przeniesiony po raz kolejny na urlop zdrowotny, zamieszkał w domu księży emerytów. Po roku skierowano go na rezydenta w parafii Ostrowite Słupeckie (27 VI 1996). Zwolniony 9 XII 1997 r. na usilną prośbę proboszcza, został przyjęty przez proboszcza parafii Ostrowąż, Jana Matusiaka, gdzie miał zamieszkać do 30 VI 1978 r. na prawach rezydenta. Pozostał tam jednak do 2 X 2000 r. Mianowany 2 X 2000 r. proboszczem w Woli Pierowej, wytrwał tam do 27 VIII 2001 r. Następnie skierowano go do Hospicjum „Przemiana i Trwanie” w Nałęczowie, gdzie przebywał do 24 VI 2002 r. Po powrocie z Nałęczowa został ponownie rezydentem u ks. Matusiaka. Zmarł w Ostrowąsie 17 VIII 2011 r. Został pochowany na miejscowym cmentarzu parafialnym ${ }^{24}$.

Nie był łatwym człowiekiem, co było spowodowane poważną chorobą psychiczna, która wprawdzie nie zagrażała nikomu, ale poważnie utrudniała współpracę z wiernymi i kolegami.

\section{Ks. Andrzej Ciapciński, 1994-2000}

Urodził się 24 X 1960 r. w Zduńskiej Woli jako syn Józefa i Heleny z d. Krzewiak. Ochrzczony został 12 XI tego roku w kościele parafialnym Wniebowzięcia NMP w Zduńskiej Woli. W tym mieście uzyskał wykształcenie podstawowe i średnie. Świadectwo maturalne otrzymał w Liceum Ogólnokształcących dla Pracujących 26 V 1980 r. Wynika z tego, że musiał gdzieś pracować w tym czasie, ale brak na ten temat informacji w jego życiorysie. Po maturze wstąpił do Wyższego Seminarium Duchownego we Włocławku, które ukończył po sześciu latach nauki i przyjął z rąk bp. Jana Zaręby święcenia kapłańskie w katedrze we Włocławku.

Pierwszą jego placówką wikariuszowską był Ostrowąs (1 VII 1986-1 I 1989), dokąd - jako mający uzdolnienia plastyczne - został posłany do pomocy ks. Janowi Matusiakowi w przygotowaniu koronacji obrazu Matki Bożej. W tym czasie zdał egzamin magisterski na Katolickim Uniwersytecie Lubelskim, otrzymując stopień magistra teologii (21 VI 1988). Kolejne jego wikariaty to: Ślesin (1 I 1989-30 VI 1988), Szadek (30 VI 1988-30 VI 1992) i parafia Wszystkich Świętych w Sieradzu (30 VI 1992-30 VI 1994).

${ }^{24}$ W. Frątczak, Zmart ks. Józef Kuś, MDWł 94 (2011), s. 1103-1105. 
Jego pierwszą samodzielną placówką duszpasterską była parafia Drużbin (30 VI 1994-26 VI 2000), następnymi: Brudzew Kolski (26 VI 2000-3 X 2001) i Szadek (3 X 2001-18 VII 2012). Był wieloletnim dziekanem dekanatu szadkowskiego i wizytatorem religii $\mathrm{w}$ tymże dekanacie. Pełnił także, na prośbę komendanta straży pożarnej w Zduńskiej Woli, obowiązki kapelana straży pożarnej oraz kapelana policji państwowej w Zduńskiej Woli. Analogiczne funkcje pełnił w komendzie straży i policji w Poddębicach, na prośbę tamtejszych komendantów.

Obdarzony godnością kanonika honorowego kapituły w Sieradzu w 2001 r., a następnie prałata archidiakona w tej kapitule w 2003 r. W 2009 r. został mianowany kapelanem papieskim.

Zmarł po długim cierpieniu w szpitalu w Łodzi w dniu 19 VII 2012 r. Jego ciało złożono do grobu w Zduńskiej Woli w grobowcu rodzinnym ${ }^{25}$.

Obecnie żyje jeszcze dwóch proboszczów parafii Drużbin: ks. Jan Zenon Szczęsny, proboszcz parafii Drużbin w latach 2000-2007, i aktualny proboszcz, ks. Dariusz Sujewicz, którzy jako żyjący nie mają jeszcze swoich biogramów.

Publikacja powyższych biogramów jest przygotowaniem do opracowania monografii tej parafii. Ich zamieszczenie w czasopiśmie, którego treść jest eksponowana także w Internecie, ma ten sens, że może znajdą się badacze, którzy potrafią je uzupełnić, co pozwoli na pełniejsze opracowanie dziejów parafii Drużbin.

\section{PASTORS OF THE DRUŻBIN PARISH (FROM XVI CENTURY)}

\section{SUMMARY}

In the study of the history of each parish a lot of attention is paid to people connected with the parish, and especially the pastors whose activities have a great impact on the pastoral life of the parish, but also on activities of the entire community outside the parish, such as social activities, cultural, national, charitable, etc. Studies in priest biographies also show the impact of their social background on the pastoral activities, as well as their approach to ministry. This article contains biographies of all known priests of this parish until recent time, and vicars who have worked in this parish.

25 Tenże, Zmart ks. Andrzej Ciapciński, MDWł 95 (2012), s. 835-836. 